\title{
Towards a Modeling Framework for Service-Oriented Digital Ecosystems
}

\author{
Rubén Darío Franco, Angel Ortiz, \\ Pedro Gómez-Gasquet, and Rosa Navarro Varela \\ Research Centre on Production Management and Engineering, \\ Universidad Politécnica de Valencia \\ Edificio 8B, Acceso L, Planta 2 \\ 46022 Valencia, Spain \\ dfranco@cigip.upv.es
}

\begin{abstract}
Reference modeling for collaborative networks has been identified as a key topic in consolidating this new scientific discipline. Earlier contributions on this field have provided a solid initial framework and they are considered starting points for this work. Based on two well-known approaches, the CIMOSA and ARCON modeling frameworks, what this work proposes is a set of modeling constructs for $\mathrm{CNO}$ modeling under a service-orientation perspective. Service Entities are incorporated as a third approach that may be considered if service ecosystems are being modeled.
\end{abstract}

Keywords: Collaborative Networks Reference Modeling, Service Ecosystems, Service Oriented Architectures.

\section{Introduction}

Considered as a commonly-agreed framework for understanding the significant concepts, entities, and relationships of some domain, Reference Modeling in the Collaborative Networks domain has been identified as a research topic that needs to be further developed [1].

Reference models are intended to provide a conceptual basis on top of which systems designers and implementers may build robust solutions for specific domains.

The main goal of this paper is to provide an initial set of modeling constructs for CNO modeling if service-orientation is being also considered.

The work has been structured in four sections. Besides this introduction, Section 2 reviews three complementary approaches that will be adopted, are introduced. Section 3 describes the approach and, finally, Section 4 briefly discusses the need, expected contribution and further research steps.

\section{CNO Reference Modeling}

Developing reference models is a complex task which requires a lot of effort. Actually, most well-recognized initiatives come from heavily-contributed large research 
projects. Both the AMICE [2] and ECOLEAD [3] consortiums involved several worldwide partners in developing CIMOSA and ARCON proposals, respectively. Being considered inspirational sources of this work, next sections will briefly describe both initiatives in order to better focus the contribution.

\subsection{ARCON Reference Modeling Framework}

In [4] a comprehensive modeling framework is introduced. A Reference Modeling Framework for Collaborative Networks (ARCON) is the result of developing a slid conceptual base intended to support different modeling levels ranging from General Representations of CNO up to detailed and concrete manifestations as Professional Virtual Communities or Virtual Labs.

Based on information collected from previous initiatives and developments of ECOLEAD project, proponents combine three main dimensions which are supposed to cover CNO (specifically its manifestations) modeling needs.

As it was mentioned earlier, developing a reference model for a specific domain may involve several people and take several years to reach its mature stage. Actually, in [], authors argue that ARCON represents just a first step in that direction and more research contributions will be needed.

What this work is providing is just a minor step in that way. Specifically, in Section 3, a set of building blocks is provided for each modeling intent layer (GR, SM and IM) but this proposal is only considering the CNO modeling from its Endogenous perspective.

\subsection{CIMOSA Building Blocks for CIM Modeling}

The Open Systems Architecture for CIM (Computer Integrated Manufacturing), initiative carried out by the AMICE consortium, perhaps it may be considered one of the most influential works of the Enterprise Engineering body of knowledge.

Initially conceived as an open architecture for manufacturing systems, its main concepts have influenced many other works. Specifically, the Virtual Enterprise Reference Architecture (VERAM) [5] and more recently ARCON, included implicit or explicit references to some of its underlying concepts.

The CIMOSA modeling framework is also characterized by three dimensions:

- Genericity dimension: related to the degree or particularization of created models. It goes from generic building blocks, intended for general purpose models, to specific company-wide ones.

- Modeling dimension: provides modeling support from a systemic perspective, going from requirements up to the description of system implementation.

- View dimension: this dimension provides users with different perspectives intended to model near-orthogonal abstractions of the system being modeled.

In terms of building blocks, a comprehensive list has been provided. Main CIMOSA building blocks are detailed in [6]. 


\subsection{Service Entities for CNO Reference Modeling}

Service Entities paradigm has been proposed as a complementary approach of Virtual Breeding Environments (VBE) and Virtual Organizations (VO) management practices and they are considered a key component of the next generation of VBE Management Systems [6].

In their simplest form, Service Entities represent abstracted specifications of actual entities existing in some specific domain, in terms of its attributes and methods (business services) needed to define their behavior. In [7], has been discussed how SE may be used to support CNO reference modeling, mainly from their Functional, Structural and Informational perspectives.

\section{A Modeling Framework for Service-Oriented Digital Ecosystems}

Based on the above mentioned approaches, next sections will describe a three-layered approach for the identification of the main building blocks in CNO reference modeling. First, a description of building blocks for CNO General Representation is introduced. This layer considers generic building blocks that may be used to describe many CNO manifestations.

Next, Specific Modeling (SM) building blocks are introduced. Most of constructs are derived from GR layer and, complementarily, two service-oriented specific ones are given:

- Digital business service interface: which is intended to support the definition of business services that $\mathrm{CNO}$ members may need to define in order to properly support CNO service-orientation approach

- Abstract Service Entity: this construct will be used to represent actors (i.e. resources) of the $\mathrm{CNO}$ which will be providing such business service interfaces.

At the Implementation level, main contribution includes two related constructs which can be used to describe their implementation details: Web Services and Concrete Service Entity.

\subsection{General Representation (GR) Modeling Constructs}

General Representation modeling constructs are intended to provide a common understanding framework for modeling generic descriptions and requirements of collaborative networks despite their nature and specific class.

Figure 1 provides an overview of main constructs and their relationships. Complementarily, Table 1 includes a brief description of such constructs. Previous contributions are indicated. 


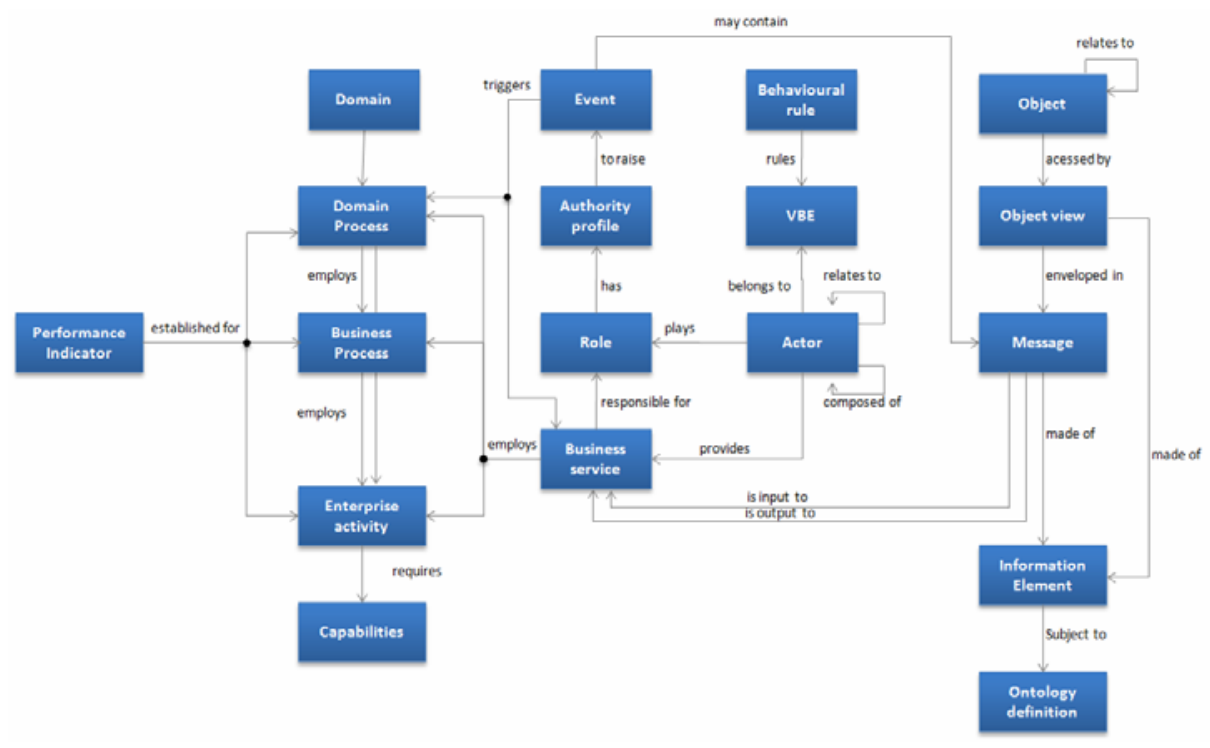

Fig. 1. CNO General Representation building blocks

Table 1. Main modeling constructs for CNO General Representation (GR)

\begin{tabular}{|c|c|c|}
\hline Construct & Description & Dimension \\
\hline Domain & $\begin{array}{l}\text { Defines the functional areas subject to system analysis and } \\
\text { implementation. }\end{array}$ & Functional \\
\hline $\begin{array}{l}\text { Domain } \\
\text { processes }\end{array}$ & $\begin{array}{l}\text { DPs are stand-alone processes triggered by nothing but } \\
\text { Events and producing defined end results. They encapsulate } \\
\text { a well-defined set of (network) functionality and behavior. }\end{array}$ & Functional \\
\hline $\begin{array}{l}\text { Business } \\
\text { processes }\end{array}$ & $\begin{array}{l}\text { BPs are user-defined sub-processes of Domain Processes } \\
\text { defining pieces of network behavior. They are made of } \\
\text { other Business Processes and/or Enterprise Activities. }\end{array}$ & Functional \\
\hline $\begin{array}{l}\text { Enterprise } \\
\text { activities }\end{array}$ & $\begin{array}{l}\text { Define the network functionality as elementary tasks de- } \\
\text { fined by their inputs, their outputs, their function and their } \\
\text { required capabilities. }\end{array}$ & Functional \\
\hline Events & $\begin{array}{l}\text { Describe real-world happenings, timers or requests to do } \\
\text { something in the network. They activate the processing of } \\
\text { the DP (and possibly the BP) of the network. }\end{array}$ & Functional \\
\hline $\begin{array}{l}\text { Performance } \\
\text { indicator }\end{array}$ & $\begin{array}{l}\text { Performance Indicators are related to specific DP, BP or } \\
\text { EA of the network and their definition includes both target } \\
\text { goals and constrained limits. }\end{array}$ & Functional \\
\hline $\begin{array}{l}\text { Business } \\
\text { service }\end{array}$ & $\begin{array}{l}\text { A business service represents a "business interface" that } \\
\text { any member of the network makes available to third parties } \\
\text { by means of an interface specification }\end{array}$ & Functional \\
\hline Actor & $\begin{array}{l}\text { Each individual network member (or candidate). They may } \\
\text { represent organizations, individuals, systems or machines } \\
\text { being able to provide business services. }\end{array}$ & Organization \\
\hline Role & $\begin{array}{l}\text { Roles are played by actors and, depending on the network } \\
\text { type, they may assume several roles along their life-cycle. }\end{array}$ & Organization \\
\hline
\end{tabular}


Table 1. (continued)

\begin{tabular}{|c|c|c|}
\hline Construct & Description & Dimension \\
\hline VBE & $\begin{array}{l}\text { Virtual Breeding Environments represent containers where } \\
\text { specific CNO instances may be launched and where actors } \\
\text { belong to. }\end{array}$ & Organization \\
\hline $\begin{array}{l}\text { Behavioral } \\
\text { rule }\end{array}$ & $\begin{array}{l}\text { Behavioral rules constrain in the sense that is described in } \\
\text { E4 ARCON's perspective. }\end{array}$ & Organization \\
\hline Object & $\begin{array}{l}\text { Describe generalised entities (or objects) of the network } \\
\text { which can thought as a whole. }\end{array}$ & Information \\
\hline Message & $\begin{array}{l}\text { Represent the basic exchange mechanism used for proc- } \\
\text { esses activation and events generation. }\end{array}$ & Information \\
\hline $\begin{array}{l}\text { Information } \\
\text { elements }\end{array}$ & $\begin{array}{l}\text { Describe elementary, i.e. atomic, pieces of information as } \\
\text { perceived by users. }\end{array}$ & Information \\
\hline $\begin{array}{l}\text { Ontology } \\
\text { definition }\end{array}$ & $\begin{array}{l}\text { Express constraints on lnformation Elements to ensure their } \\
\text { consistency. }\end{array}$ & Information \\
\hline
\end{tabular}

\subsection{Specific Modeling (SM) Constructs}

Specific Modeling Constructs refer to a set of building blocks that can be used to model specific types of CNO. Their specification will serve as base for modeling specific types of CNO and they may be based on currently available GR building blocks.

Figure 2 shows the constructs of this layer and their main relationships. Complementarily, Table 2 includes a brief description of them where previous contributions are highlighted.

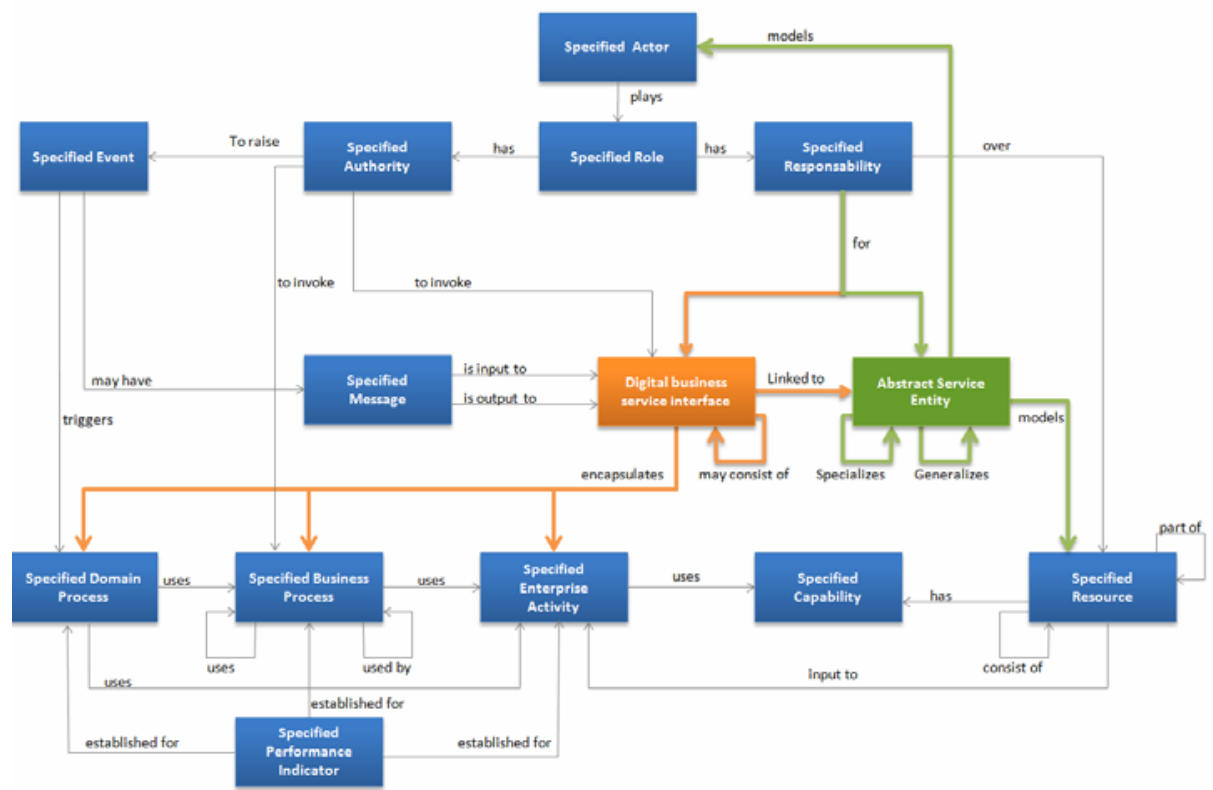

Fig. 2. CNO Specific Modeling building blocks 
Table 2. Modeling constructs for CNO Specific Modeling (SM)

\begin{tabular}{|c|c|c|}
\hline Construct & Description & Dimension \\
\hline $\begin{array}{l}\text { Specified } \\
\text { Domain } \\
\text { Process }\end{array}$ & Formal specifications of Domain Processes. & Functional \\
\hline $\begin{array}{l}\text { Specified } \\
\text { Business } \\
\text { Process }\end{array}$ & $\begin{array}{l}\text { Formally defined specifications of Collaborative Business } \\
\text { Processes. They are defined by their triggering condition } \\
\text { and Process Behaviour }\end{array}$ & Functional \\
\hline $\begin{array}{l}\text { Specified } \\
\text { Enterprise } \\
\text { Activity }\end{array}$ & $\begin{array}{l}\text { Specification of Enterprise Activities defined by their In- } \\
\text { puts, Control, Resources, Outputs and Resources. }\end{array}$ & Functional \\
\hline $\begin{array}{l}\text { Specified } \\
\text { Performance } \\
\text { Indicator }\end{array}$ & $\begin{array}{l}\text { Formal definition of Performance Indicators linked to } \\
\text { operational processes and resources. }\end{array}$ & Functional \\
\hline $\begin{array}{l}\text { Digital } \\
\text { business } \\
\text { service } \\
\text { interface }\end{array}$ & $\begin{array}{l}\text { Linked to GR-Business Services, they represent the formal } \\
\text { definition of a business service interface (mainly in terms } \\
\text { of inputs, outputs and expected functionality) that will be } \\
\text { provided by means of digital networks. }\end{array}$ & Functional \\
\hline $\begin{array}{l}\text { Abstract } \\
\text { Service Entity }\end{array}$ & $\begin{array}{l}\text { Representing a type of Actor, they provide functional capa- } \\
\text { bilities by means of their abstract digital service definitions. }\end{array}$ & Organization \\
\hline $\begin{array}{l}\text { Specified } \\
\text { Message }\end{array}$ & $\begin{array}{l}\text { Formal definition of messages to be exchanged inside the } \\
\text { network when DP and BP are executed. }\end{array}$ & Functional \\
\hline $\begin{array}{l}\text { Specified } \\
\text { Event }\end{array}$ & $\begin{array}{l}\text { Formally defined specifications of both external and inter- } \\
\text { nal Events }\end{array}$ & Functional \\
\hline $\begin{array}{l}\text { Specified } \\
\text { Resource }\end{array}$ & $\begin{array}{l}\text { They provide the specified Capabilities which meet or } \\
\text { exceed the required Capabilities defined at the GR defini- } \\
\text { tion level }\end{array}$ & Resource \\
\hline $\begin{array}{l}\text { Specified } \\
\text { Capability }\end{array}$ & $\begin{array}{l}\text { Provided by specified Resources, meet or exceed the re- } \\
\text { quired Capabilities defined at the GR Modeling Level }\end{array}$ & Resource \\
\hline $\begin{array}{l}\text { Specified } \\
\text { Responsibility }\end{array}$ & $\begin{array}{l}\text { Formally defined engineering responsibilities for the crea- } \\
\text { tion, and maintenance of specific modeling activities }\end{array}$ & Organization \\
\hline $\begin{array}{l}\text { Specified } \\
\text { Actor }\end{array}$ & $\begin{array}{l}\text { Formal identification of entities involved in the CNO. At } \\
\text { this modeling level they only are identified as classes or } \\
\text { types. }\end{array}$ & Organization \\
\hline $\begin{array}{l}\text { Specified } \\
\text { Role }\end{array}$ & $\begin{array}{l}\text { Directly linked to actors, a role is assumed by one or more } \\
\text { actors, depending on network specific constrains. }\end{array}$ & Organization \\
\hline $\begin{array}{l}\text { Specified } \\
\text { Authority }\end{array}$ & $\begin{array}{l}\text { are formally assigned engineering responsibilities for the } \\
\text { creation, and maintenance of specific modeling activities }\end{array}$ & Organization \\
\hline
\end{tabular}

\subsection{Implementation Modeling (IM) Constructs}

Implementation Modeling Constructs refer to a set of building blocks that can be used to model specific instances of specific CNO models. They may be based on currently available SM building blocks. Figure 3 shows the constructs of this layer and their main relationships. Complementarily, Table 3 includes a brief description of them where previous contributions are highlighted. 


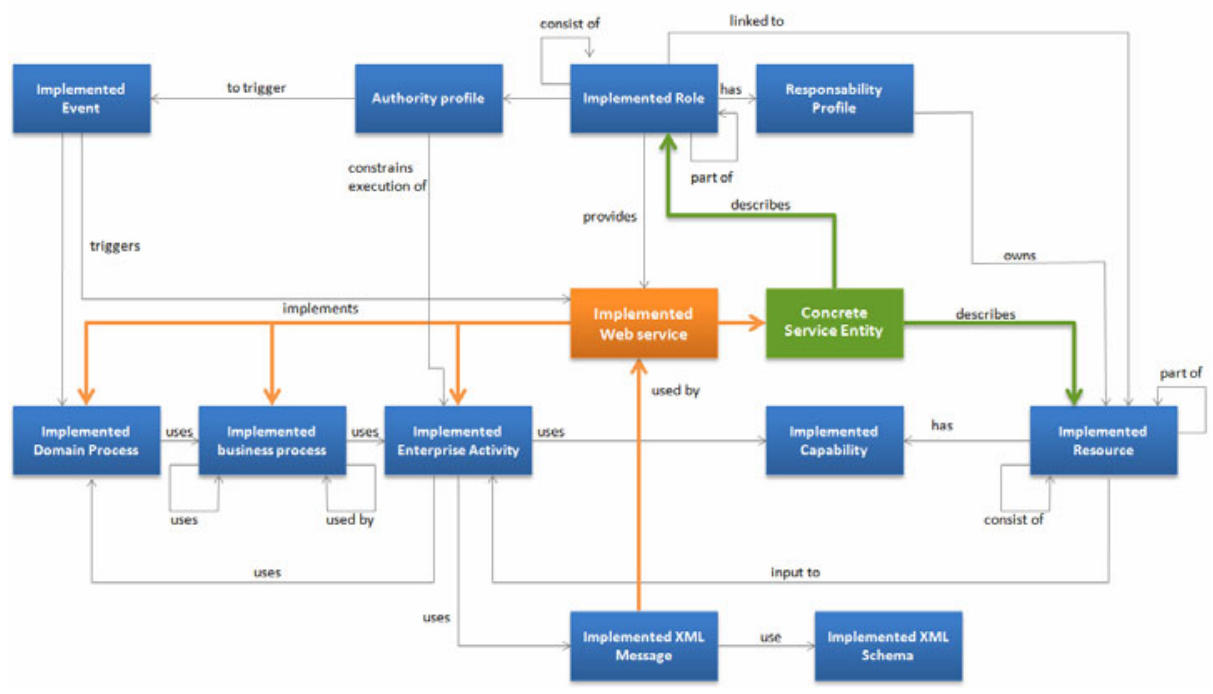

Fig. 3. CNO Implementation Modeling building blocks

Table 3. Modeling constructs for CNO Implementation Modeling (IM)

\begin{tabular}{|c|c|c|}
\hline Construct & Description & Dimension \\
\hline $\begin{array}{l}\text { Implemented } \\
\text { Domain } \\
\text { Process }\end{array}$ & Describe the implemented Domain behavior & Functional \\
\hline $\begin{array}{l}\text { Implemented } \\
\text { business } \\
\text { process }\end{array}$ & $\begin{array}{l}\text { Describe the implemented flow of control for a part of a } \\
\text { DP. }\end{array}$ & Functional \\
\hline $\begin{array}{l}\text { Implemented } \\
\text { Enterprise } \\
\text { Activity }\end{array}$ & $\begin{array}{l}\text { Describe the implemented functionality and indicate re- } \\
\text { sources needed to execute it. }\end{array}$ & Functional \\
\hline $\begin{array}{l}\text { Implemented } \\
\text { Event }\end{array}$ & $\begin{array}{l}\text { Describe how enterprise events initiate action by the physi- } \\
\text { cal system of the enterprise }\end{array}$ & Functional \\
\hline $\begin{array}{l}\text { Implemented } \\
\text { Resource }\end{array}$ & $\begin{array}{l}\text { Describe resources which are derived from Specified Re- } \\
\text { sources. }\end{array}$ & Resource \\
\hline Implemented & Describe capabilities which are provided by Implemented & Resource \\
\hline Capability & $\begin{array}{l}\text { Resources and which comply with Specified Capabilities } \\
\text { defined at the Design Specification Modelling Level. }\end{array}$ & \\
\hline $\begin{array}{l}\text { Implemented } \\
\text { authority } \\
\text { profile }\end{array}$ & Define engineering and operational responsibilities & Organization \\
\hline $\begin{array}{l}\text { Implemented } \\
\text { role }\end{array}$ & $\begin{array}{l}\text { CNO Specific roles that may be assumed by Implemented } \\
\text { resources and Concrete Service Entities }\end{array}$ & Organization \\
\hline $\begin{array}{l}\text { Implemented } \\
\text { responsibility } \\
\text { profile }\end{array}$ & Assign engineering and operational responsibilities & Organization \\
\hline
\end{tabular}


Table 3. (continued)

\begin{tabular}{|c|c|c|}
\hline Construct & Description & Dimension \\
\hline $\begin{array}{l}\text { Web } \\
\text { service }\end{array}$ & $\begin{array}{l}\text { Implemented digital business service interface which con- } \\
\text { stitutes the expected digital functionality provided by them }\end{array}$ & Information \\
\hline $\begin{array}{l}\text { Implemented } \\
\text { XML } \\
\text { Message }\end{array}$ & $\begin{array}{l}\text { Describe XML-based messages that are going to be used } \\
\text { for CNO information sharing and coordination mechanism. }\end{array}$ & Information \\
\hline $\begin{array}{l}\text { Implemented } \\
\text { XML Schema }\end{array}$ & $\begin{array}{l}\text { Describe implemented XML-schemas that will be used to } \\
\text { validate messages and ontological validation. }\end{array}$ & Information \\
\hline $\begin{array}{l}\text { Concrete } \\
\text { Service Entity }\end{array}$ & $\begin{array}{l}\text { Actual instances of Abstract Services Entities linked to } \\
\text { implemented resources and able to provide their expected } \\
\text { capabilities }\end{array}$ & Organization \\
\hline
\end{tabular}

\section{Brief Discussion}

Reference modeling in the Collaborative Networks domain has been identified as a key research topic that needs to be further addressed.

Earlier contributions in this field have provided solid initial foundations and this work has introduced a first attempt to provide a set of modeling constructs for CNO, based on three converging research streams: the CIMOSA Modeling Framework, ARCON Modeling Framework and Service Entities approach.

As a result, an overall framework has been made available for systems architects and developers.

We are aware that developing this kind of models requires deep research community consensus. Cause of that, next research steps will include its submission to public bodies as the Society for Collaborative Networks (SOCOLNET) for further enrichment and validation.

\section{References}

1. Camarinha-Matos, L., Afsarmanesh, H.: Towards a reference model for Collaborative Networked Organizations. In: Proceedings of BASYS 2006. Information Technology for Balanced Manufacturing Systems. Springer, Heidelberg (2006)

2. AMICE Consortium, http: / / cimosa.cnt.pl/Docs/Primer/primer2 . htm

3. ECOLEAD Project (2009)

4. Camarinha-Matos, L., Afsarmanesh, H.: Collaborative Networks: Reference Modeling. Springer, Heidelberg (2008)

5. VERAM. Virtual Enterprise Reference Architecture and Methodology, http://cic.vtt.fi/projects/globemen/book/01_zwegers2.pdf

6. Franco, R.D., Ortiz Bas, A., Lario, F.: Modeling extended manufacturing processes with service-oriented entities. Service Business 3(1) (March 2009)

7. Franco, R.D., Ortiz Bas, A., Prats, G., Navarro Varela, R.: Supporting Structural and Functional Collaborative Networked Organizations Modeling with Service Entities. In: Leveraging Knowledge for Innovation in Collaborative Networks, pp. 547-554. Springer, Heidelberg (2009) 